\title{
Article
}

\section{Seasons in the Abyss: Heavy Metal As Liturgy}

Scott, Niall William richard

Available at http://clok.uclan.ac.uk/28188/

Scott, Niall William richard ORCID: 0000-0001-5120-4132 (2014) Seasons in the Abyss: Heavy Metal As Liturgy. Diskus, 16 (1). pp. 12-29. ISSN 0967-8948

It is advisable to refer to the publisher's version if you intend to cite from the work. https://doi.org/10.18792/diskus.v16i1.2

For more information about UCLan's research in this area go to http://www.uclan.ac.uk/researchgroups/ and search for <name of research Group>.

For information about Research generally at UCLan please go to http://www.uclan.ac.uk/research/

All outputs in CLoK are protected by Intellectual Property Rights law, including Copyright law. Copyright, IPR and Moral Rights for the works on this site are retained by the individual authors and/or other copyright owners. Terms and conditions for use of this material are defined in the policies page.

\section{CLoK}

Central Lancashire online Knowledge www.clok.uclan.ac.uk

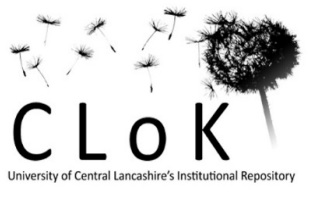




\title{
D I S K U S
}

The Journal of the British Association for the Study of Religions (www.basr.ac.uk) ISSN: 0967-8948

Diskus 16.1 (2014), 12-29

\section{Seasons in the Abyss: Heavy Metal as Liturgy}

\author{
Niall Scott \\ Senior Lecturer in Ethics, University of Central Lancashire \\ School of Education and Social Science \\ nwrscott@uclan.ac.uk
}

\begin{abstract}
In the past few years the music and culture of heavy metal has drawn attention to itself in its relationship to mysticism, religious practice and theology. In this paper I aim to show that heavy metal, giving specific attention to the extreme subgenre of black metal, can function in terms of liturgy. I claim that it can carry with it the sense of duty ascribed to the Greek origin of the term, but also be seen as having a parallel with liturgy in terms of a spiritual rite and invoke deeper metaphysical associations with liturgy as engendering an insight into the transcendent. This metaphysical understanding of liturgy is borrowed from Catherine Pickstock, who I contend opens up the case for heavy metal to be considered in liturgical terms, but not without criticism of her assumptions regarding art and spectacle which she holds to offer only a pseudo liturgy in the context of modernity. In this piece I aim to speak of an encounter between black metal with an apophatic liturgy; a liturgy of negation, where one can use words and structures to annul meaning and structure. This apophatic liturgy provides an opportunity to explore the possibilities that can provide insights into the relationship between mysticism and liturgy by challenging what liturgy refers to; in the case of black metal it refers to a meaningless void, rather than an object of worship.
\end{abstract}

\section{Introduction}

The field of heavy metal studies has come of age in the past few years, and has established itself as a discipline in its own right (Brown, 2011). The hydraic nature of heavy metal culture spills over into the wide range of subjects that are open for study and consideration, religious studies and theology being themes that frequently rear their heads. I first considered the relationship between heavy metal and liturgy at the 2005 Download festival, Donington, England, where $A$ Sunday Service was held by the musician and comedian Henry Rollins, presenting part of his spoken word tour under the description of a 'sermon'. This event, which started at 10:00am, to a packed 
tent for several thousand fans, was a fairly impressive turnout at such an hour in festival terms. In a sense, festival events in the heavy metal calendar such as the UK's Download festival at Donnington in June, the Bloodstock festival in August or Hammerfest held in March, Wacken in Germany, as well as other festivals worldwide, have also become pilgrimage sites for the metal musician and devotee (BBC Arena, 2014; Dunn, 2005). They span the year and punctuate the seasons. Regarding the music events and gigs that happen throughout the year, it is not hard to argue a case that the heavy metal events have many features that could be held in common with acts of worship and liturgy by way of metaphor and simile. The festival events that occur year round have resonances of a liturgical calendar. At a descriptive level these parallels can extend into the devotion of fans and ritualistic ceremonial behaviors. The heavy metal live event is awash with ritual, symbolism and meaning, but such parallels can easily be made with a host of other communities, practices and events in contemporary popular and mass culture.

So what is it about heavy metal that allows it to be identified as having a liturgical nature? I aim to explore the possibility of treating and understanding heavy metal culture in liturgical terms: as a liturgy of negation, an apophatic liturgy. My focus will be on discussing this mainly through the extreme metal genre of black metal, but other subgenres of heavy metal are also relevant. Briefly, black metal is a subgenre of heavy metal music and culture that arguably has its origins in Norway in the early 1990s and is originally associated with expressing a perspective that was explicitly satanic (Hagen, 2011, p.182), melancholic, and associated with Nordic folk identities and mythology. The subgenre today has moved on through a series of successive 'waves' of development diversifying in its subject matter, but remaining a niche, underground scene, most recently accounted for in a thorough history of the movement by Dayall Patterson (2013). It includes performance art, eco-activism in the work of Wolves in the Throne Room (Hopper, 2009) and even mafia politics in Abgott's Godfather in Black (2009). Stylistically the music is different from other forms of heavy metal in its use of synthesizers, fast tremolo picking guitar technique, 'blast-beat' drumming and high pitched screamed vocals and an all-round symphonic sound.

In this paper, I am making the claim that heavy metal can be treated as a liturgy of negation, as an apophatic liturgy, both as a goal to be aimed at, but also already manifestly present in some areas of heavy metal. It a goal to be aimed at because heavy metal has as part of its expression a link to mass and popular culture as a commodified product and its marketization that can make it merely a superficial candidate for a liturgical view. As will become evident towards the end of this piece, there is a problem in heavy metal being treated as liturgy if it is nothing other than a spectacle, but I challenge this view. I have argued elsewhere that although beset with difficulties, it is possible to make a case for heavy metal culture to escape the trappings of the market and present a threating stance in its maintenance of a range of paradoxical positions (Scott, 2011) 


\section{Heavy Metal and Religion}

The relationship between religion, spirituality and heavy metal have, in recent times been explored in interdisciplinary contexts. Heavy metal is easily identified as at odds with Christianity, even as anti-Christian, especially with regard to the genres of black metal and death metal (Purcell, 2003, p. 41), but the relationship is far more complex than this, the various subgenres of heavy metal promoting or expressing interest in pagan, occult, shamanic, gnostic and atheistic positions and beliefs (Till, 2010, p.125). Marcus Moberg has made several studies of Christian heavy metal, identifying its 'peculiar' nature (Moberg, 2012), recognizing the antagonism in heavy metal culture to Christianity. He further refers to Christian heavy metal as occupying a "double controversy" in straddling both evangelical Christianity and the culture of metal music (Moberg, 2011, pp.85-99). A study of the French annual heavy metal festival Hellfest has shown how the organization dealt with and resolved tensions within the local community and the Roman Catholic Church's disquiet and misunderstandings on the content and diversity of heavy metal music and culture (Guibert, and Sklower, 2013 p.98-113). Both Mark Levine and Pierre Hecker have developed extensive research into the relationship heavy metal and Islamic culture (Levine, 2008; and Hecker, 2012a, b) Further, the Black Metal Theory project initiated in Brooklyn in 2009 is replete with theorizing on the synergy between the extreme genre of Black metal and amongst other fields, theology, esoterica, Gnosticism and medieval Christian thought (Masciandaro, 2010). I have argued that the black metal event provides the opportunity for a confessory space without hope of absolution (Scott, 2010) and that the word can be slaughtered and putrefied in the black metal rite, as a form of black mass. The work of Owen Coggins (this volume) expands on the relationship between heavy metal and spirituality in its consideration of the genres of doom and drone metal and meditation. It is also worth mentioning the somewhat satirical campaign to see heavy metal recognized as a religion in the UK through the National census led to more serious points being made about the association between the culture and religious belief (Alderslade, 2012). This campaign initiated by Alexander Milas, the editor at Metal Hammer Magazine and supported by Biff Bifford, lead singer of the band Saxon, led to some interesting media attention given to the relationship between heavy metal culture and religious belief, including my own contribution to a BBC radio 4 interview on the subject (Brassington, I., 2010).

The scene members and supporters of bands and the heavy metal movement in general show support and allegiance at their own expense, in common with an early understanding of the notion of liturgy as will be outlined below. Much more than simply a consumer-driven dark corner of popular culture, heavy metal presides over a way of being, a weltanschaung that transcends the superficial interests of market forces. For example Nicola Allett's work on extreme metal identifies the extreme metal connoisseur, as distancing themselves from popular mainstream music cultures, but is engaged in an important identity-work that defines boundaries of the scene's status as art and countercultural transgressive quality (Allett, 2012). In the context of this research it seems both timely and apt to look at metal in terms of liturgy. 


\section{Defining Liturgy}

Liturgy can be defined in several ways. It can be firstly understood in its original Greek legalistic term leitourgia, denoting someone (a citizen) who performs a public duty. This has carried over into its use to describe the public service performed in the temple and subsequently in the Christian context the "public official service of the church" (Fortescue, 2009 [1910]) J.H. Miller (1957, p.326) expresses the etymology as "service done for the common welfare", but he continues, pointing out that it was done at personal expense or without remuneration, broadening out to "embrace any number of actions which might have repercussions in the social and political sphere" (Miller, 1957, p.326). However, as Miller documents, in the meeting between Hellenic and Hebrew culture, the term begins to be associated exclusively with worship and charity and the communal works of Christian service. In the carrying out of certain services the liturgy has a performative component where it comes close to, but is distinct from ritual. That is, although liturgy can display features of repetition, the difference to be maintained concerns the claim that liturgy is authoritative and maintains a distinction between the sacred and the profane. He claims further that liturgy maintains the capacity to challenge social norms. (Lloyd, 2011). However, this is articulated by Lloyd in a defense of the Christian liturgy and is not without criticism.

As we shall see below, the treatment of liturgy can be broadened to a much more profound metaphysical relationship where liturgy is concerned with fusing the "most ideal with the most real" (Pickstock, 2000, p.160), where following on from a description of Plato's Utopia of Magnesia in the Laws, she holds it also to be a political category. In this understanding Pickstock identifies what is at the heart of the meaning of liturgy in a cultural and spiritual sense, recognizing those features of human cultural life that depend entirely on what she refers to as the "pre-given lifeworld" that is "characterized as at least partially in terms of repeated rhythms and patterns which make reasoning possible" (Pickstock, 2000, p.160). However I think that there are elements of all three conceptions of liturgy that are relevant in the treatment of heavy metal as liturgy- both the Greek meaning, aspects of the Christian legacy and Pickstock's position are important in the possibility of seeing heavy metal culture as having a significant liturgical quality. The support for heavy metal as a form of liturgy does however go against Pickstock's identification of how a secular modernity in art and political activity performs a parody of liturgy, which she typifies as an anti-liturgy liturgy, or a pseudo liturgy. I argue that a more detailed look at black metal, and specifically the work of the black metal band Watain, shows this not to be the case.

The use of liturgy in the context of Christian worship as a public expression of the fulfillment of the duty of worship is not just to be seen as the ceremony of worship. We can treat liturgy as an event where an expression of beliefs and principles are vocalized, and if this is the case then we can also make a claim in the heavy metal event for liturgy as a duty fulfilling public service. Music in the context of heavy metal is not simply treated as a vehicle of expression, directed towards another object of interest, in the way that Christian worship directs its music towards God. Rather in heavy metal, the 
music is the object of interest itself. It is both the expression and the essence of the culture. The Californian heavy metal band Machine Head express this well in their lyric in the song Darkness Within: "So pray to music build a shrine/Listen in these desperate times/Fill your heart with every note/Cherish it and cast afloat/ Because god is in these clef and tone/Salvation is found alone/Haunted by its melody/Music it will set you free/Let it set you free" (Flynn, R. 2011). The Polish blackened death metal group Behemoth have recently explored heavy metal in arguably a worshipful sense in their works Evangellion (2012) and The Satanist (2014), their lyrics building on research into Biblical and Gnostic texts as well as the works of Georges Bataille and Friedrich Nietzsche. They present a Dionysian inversion of Christian liturgical worship, embellishing on themes of the negative and the absent. The stage performance of Behemoth extends the worshipful nature as a parody, in its use of a pulpit-like stand behind which the singer, Nergal Darski pronounces his orations to the amassed crowd (see image below).

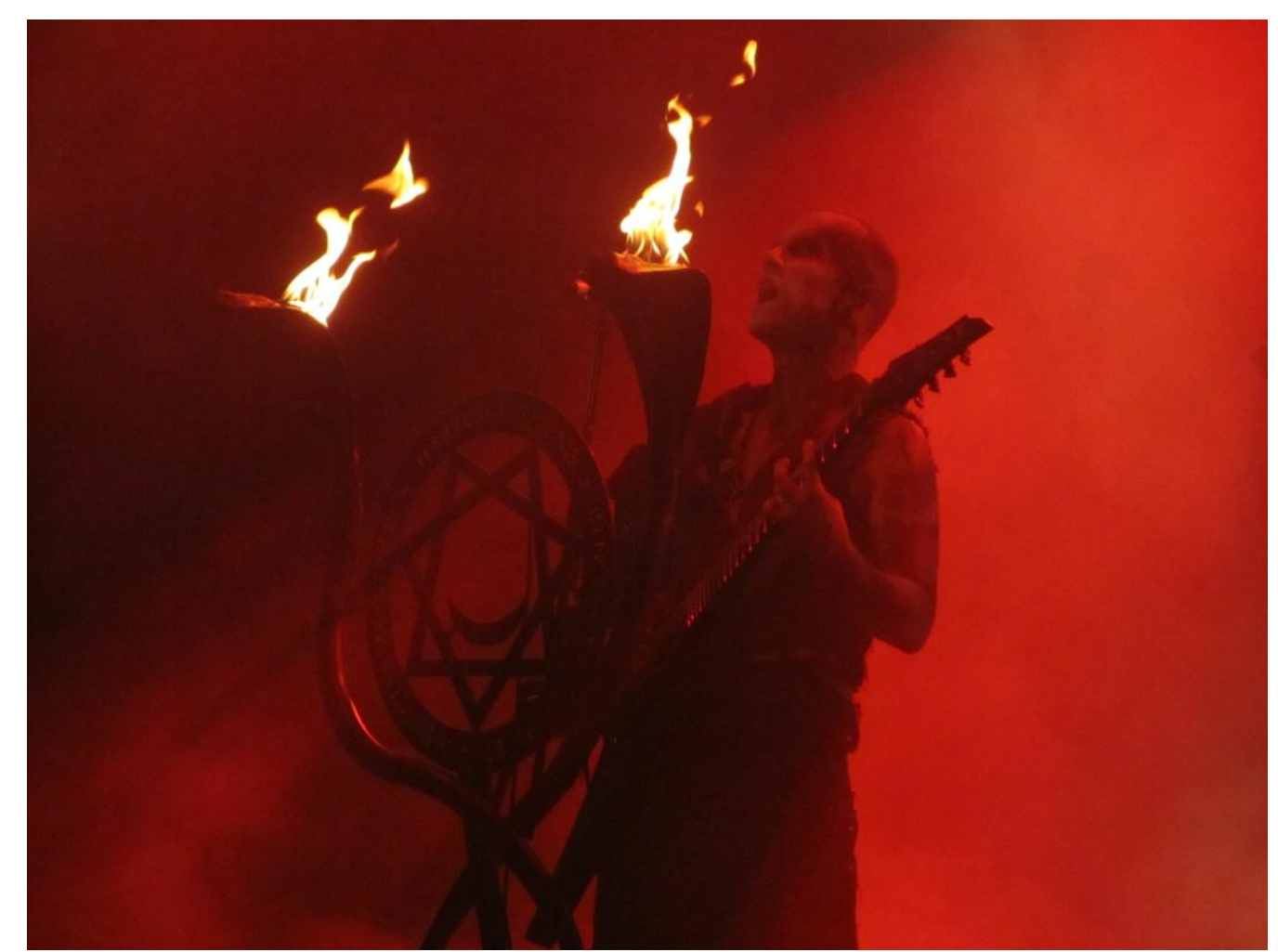

Image 1 Behemoth, Bloodstock festival, 2012, Catton Hall, Derbyshire, image@ Niall Scott

Not only do these concerts have a hymnic structure and present an expression of belief in the allegiance to heavy metal culture; the content of the work is that of negation and inversion, bounded by ritual. Indeed Behemoth's recent works of Evangelion (2009) and The Satanist (2014) provide detailed explanation of the content of the lyrics in the sleeve notes of the CD release, the rationale behind the poetry, an exegesis of the text annotated as if a concordance has been provided to understand the inaccessible, brutal scream, growl and wail in the expression of the lyrics by the vocalist.

\section{Liturgy and pseudo liturgy}


Catherine Pickstock's essay on liturgy, art and politics provides a strong foundation for the exploration of liturgy in heavy metal, however she is critical of that which appears to be liturgical, that which has all the trappings of liturgy, but is she argues not. Her argument insists that a re-engagement with liturgy is required to deal with the alienation suffered in modernity. She claims that liturgy is able to mediate between art and politics in a manner that restores the self and its everyday experiences to the ideals in which those experiences are grounded. This is in contrast to resolving and finding meaning in experience by seeking out other experiences, so as she puts it: "a modern individual may alternate between seeking refuge from public misery in private delight." (Pickstock, 2000, p.161), condemning the self to knowing the impossibility of living simultaneously in the public and private sphere. This mediation is a critical, active one in which the self can do the task of the priestly figure. This liturgical self, she holds, is a representative subject fulfilling a channeling role. Pickstock's position follows on from Durkheim's commitment to a collective moral grounding of society, but more substantially from the Frankfurt School's neo-Marxist critique of modernity, to which she specifically refers. Here, Herbert Marcuse held that mass reproduction and the availability of "art, politics religion and philosophy" are made available "for consumption through the common denominator in commodity form." (Marcuse, 1991, p.57), removing any critical engagement with such things, let alone the recognition of the grounding of value in these spheres. From this perspective, modernity is involved in the destruction of autonomy; Pickstock's argument concerning liturgy aims to restore it.

Pickstock then develops an argument for what she calls a pseudo liturgy or an anti-liturgy liturgy. This holds that the self is able to live and operate perfectly well in contemporary society, but to do so with no reference to transcendent meaning. In a superficial sense, the self still is an agent, but submissive to the demands of capitalism and the market, even in art and politics. This predicament is well articulated as a lament by the Cascadian black metal band Wolves in the Throne Room:

Why are we sad and Miserable? Because our culture has failed, we are all failures. The world around us has failed to sustain our humanity, our spirituality. The deep woe inside Black Metal is about fear that we can never return to the mythic, pastoral world that we crave on a deep subconscious level. Black Metal is also about self-loathing, for modernity has transformed us, our minds, bodies and spirit, into an alien life form; one not suited to life on earth without the mediating forces of technology (quoted in Smith, 2006).

The refusal of liturgy, that Pickstock accuses modernity of expressing goes to the heart of this transformation that Wolves in the Throne Room relate to. She writes:

To be non-liturgical means to have got rid of the differentiation between time and space, and to live in a perpetual virtual space of identical repetition. Without the closing down of diurnal activity at dusk there is no interval before sleep for the descent of the angels, no time to 
relativize man's dominion, just as the red sky of the city hides the stars from our view. (Pickstock, 2000, p.167).

An aspect of this refusal of liturgy and entertaining a pseudo liturgy is the use of spectacle to induce order as a diversion, a distraction. Where heavy metal is known only in terms of a staged musical performance, it would seem that it too succumbs to a pseudo liturgy. Even at a meta-level, where those concertgoers are distracted from the distraction of the performance in their obsession to capture in recordings and images, where audiences at live music events are an illuminated sea of devices, phones and tablets aiming to contain the event rather than simply be there, this criticism of spectacle is true. Below I will go on to argue that this can hold, but is also avoided by heavy metal as it presents an apophatic liturgy.

Andrew Edgar has risen to the challenge to expand Pickstock's work in arguing for sport to be considered in negative liturgical terms. Edgar introduces the term negative liturgy in an essay on sport as liturgy, where he defines it as the spectator and participant engaging with the "lack of transcendent meaning in modern life" (Edgar, 2012, p.31) Here he is stressing the tension that exists between the local level event (a particular match) and the substance of sport as such, or the narrative richness in a particular event. In sport for Edgar, humanity is confronted by the "meaninglessness of defeat and failure and the transitory nature of victory" (Edgar, 2012, p.34). I would hold the same to be true of heavy metal, specifically black metal, in its articulation and opening of the consideration of meaninglessness and nihilism. Edgar, however, rejects this possibility regarding music, specifically the musical performance. This fails to recognize the fact that an individual musical event is an expression of a much wider culture and identity. Heavy metal culture including all its subgenres cannot be reduced to the performance of the music, yet at the same time it is entirely focused on the music as the epitome of its identity. This is a complex relationship, continuously challenging the metal devotee to reflect on the relationship between the event and its wider significance for its universality. Where black metal focuses precisely on themes of meaninglessness, misanthropy and nihilism, it is well placed to offer the opportunity for insight that Pickstock claims: a liturgical treatment of human cultural needs. Where Pickstock places community at the heart of this, black metal and heavy metal generally throw up the consideration of human relationships in terms of community versus individuality, a heavy metal camaraderie juxtaposed by explorations of misanthropy. Rather than contradictions, these are tensions that have as their alternative not a utopian vision of community, but instead a meaningless void. The Californian black metal band Volahn expresses it thus:

We are the Circle of the Black Twilight. Spreading Kaos and Dissonance through sacred ceremonial worship. We have transcended from this mind and flesh. We exist within this darkness and dwell within its unending void of disharmony. You too will come to proclaim it's ultimate presence (Volhan, Crepusculo Negro pamphlet, quoted in Masciandaro, 2010, p.70). 


\section{Watain's Liturgy}

In the extreme genre of black metal not only do we have the image of liturgy being communicated but the content of the live event contains liturgical moments; this is evident in some of the more commercial black metal events where a theatrical stylization of religious ritual is performed- on its own terms, but also as ridicule and satire, similar to the black mass.

Picture a performance by the Swedish Black Metal band Watain. The scene is one of a gathering; band names and symbols can be read on t-shirts, patch jackets as well as on stage. These display amongst other things the virtually illegible art work of black metal band names, a conscious challenge to meaning, the incomprehensible and inaccessible being celebrated over reference and meaning. Unlike a church gathering, the anticipation of the event leads people to throng and pack to the front of the stage/altar, thronging to reach the void that is to be filled by the priestly figures of the musicians. Rather than showing guilt and unworthiness and a reluctance to come to the front, those present 'raise their horns' and claw the air in a gesture aimed at grasping the sound to come, some bellow the name of the band, others scream the word 'Satan' filling the air with irony. All at the black metal event consider themselves worthy. Anticipation is guided by the filling of a void, but it will be filled by noise accompanied by music. Incomprehensible, indistinguishable, inaccessible noise- a suggestion of melody, but primarily changes in tone of sound and syncopation are what is heard. Erik Danielson, the lead singer of Watain walks on to the stage, and lifts a chalice over his head, kneels before an altar as the smell of burning flesh from sheep carcasses that are draped over stands hanging between flaming tridents, reaches the crowd.

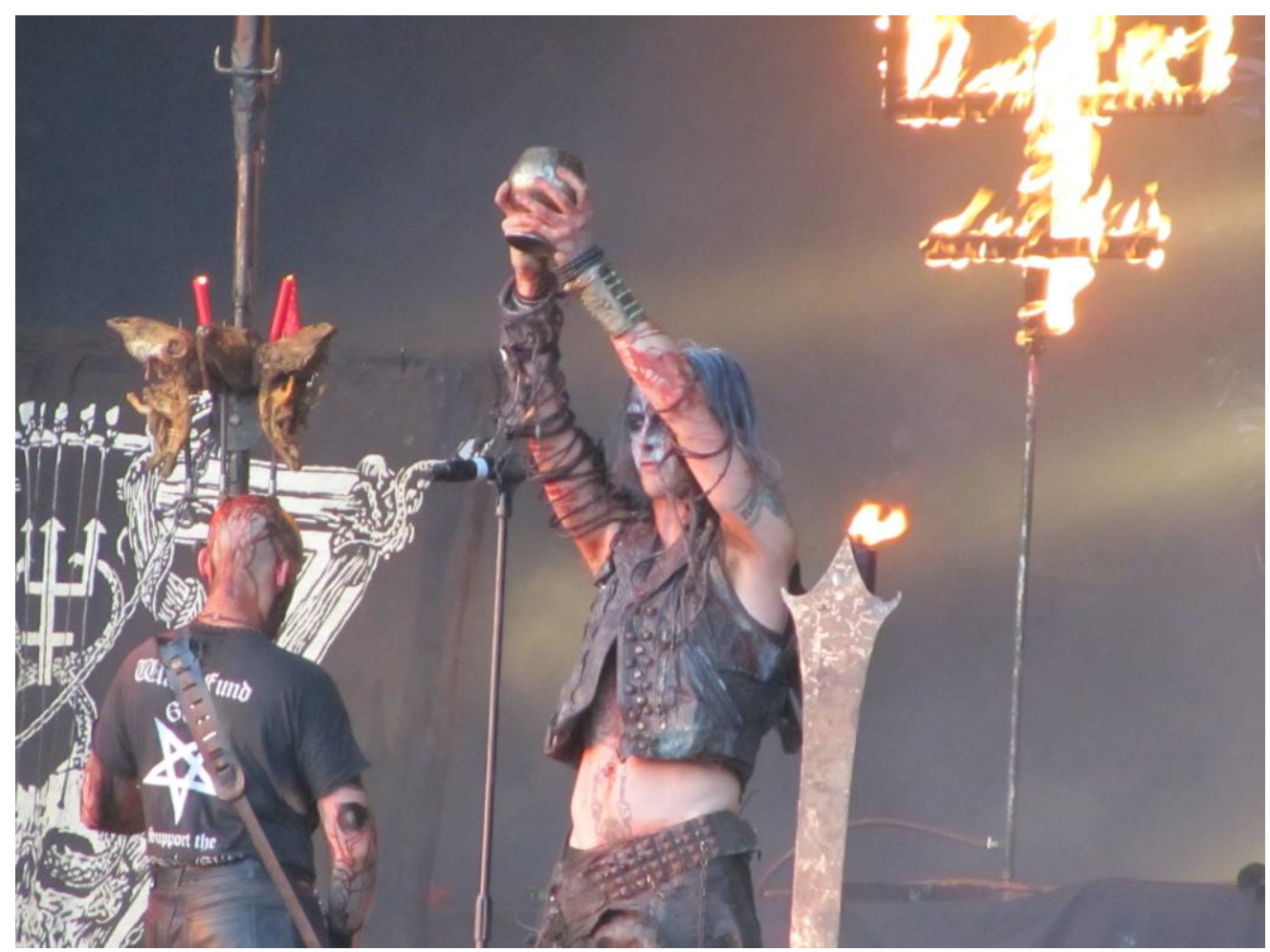

Image 2 Watain, Bloodstock festival, 2012, Catton hall Derbyshire, image (C) Niall Scott 
Once the music begins, for the most part there is no room for silence, but with continuous sound (as is also the case with drone metal) it is the recognition and memory of silence that allows one to make sense of the experience. One is confronted by a totality of noise, made comprehensible by a totality of silence. Words are putrefied to growls and slaughtered; as is the word of God: "For I am the one to bring the demise of the bearer of thorns" (Danielsson, 2000).

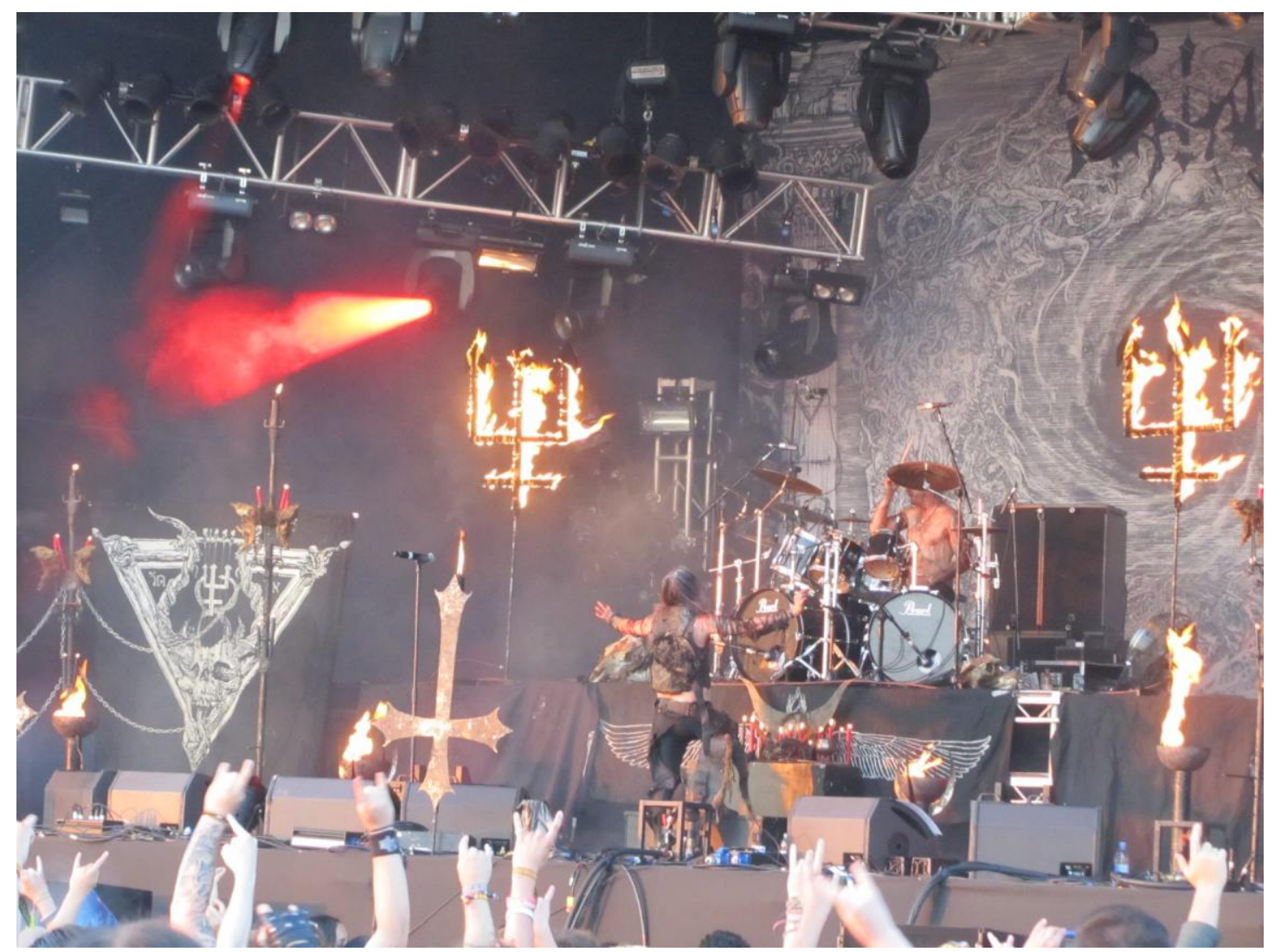

Image 3 Watain Bloodstock festival, 2012, Catton Hall, Derbyshire, image (C) Niall Scott

The silence is recognized as that which exists before speech, before the band play, before the event begins and importantly the silence before creation. This is a liturgy that calls into presence a silence through nothing other than noise. In line with Masciandaro's claim, this is a sound, a noise that heavy metal delivers where as a deictic art- "It calls attention to the overlooked, to the nearly forgotten, and even more palpably to the reality of the questioner, the self itself" (Masciandaro, 2009).

Erik Danielsson has described black metal as "music that can manipulate the will or lead people into action, evoking devotion and passion." This expression harks back directly to the above noted feature of Christian liturgy, where it was described as having a capacity to challenge social norms. In black metal we find a liturgy of opposition, articulating the transcending of human limitations. "What we present with Watain is a symbol of our beliefs" (Danielsson, 2013). Indeed, a deep understanding of the history of black 
metal will see the dramatization of beliefs encoded in the live event. Like the mass, divisions are present as well as communities: the coming together is a gathering and an expression of separation from ideologies social structures and concepts. At the same time oppositional ideals are being expressed. In this sense black metal gatherings are also political events.

The crowd are not party to the preparations prior to the stage show, nor are they present at the consequential event and in this manner, the musicians carry with them a priestly obligation offering to those present the opportunity for contemplating the transcendent, reflecting on the servitude held to be a definitional characteristic of liturgy mentioned above. As Erik Danielson claims on Opus Diaboli, music has a higher transcendental purpose and its essence is spiritual. Thus the listener is party to an absence prior to and following on from the ritualistic component of the artist's performance. This absence is reflective of the apophatic component of black metal: prior to and following the event there is only a void. Journalist and writer Tom O'Boyle once described their music as "Tearing open a portal to the other side" (O'Boyle, 2012).

The aims of Watain develop and demonstrate heavy metal's liturgical feature well, most importantly heavy metal as fusing the ideal with the real. It is worth quoting Danielsson's justification for the band's project at length from the opening statement of Watain's Opus Diaboli:

Let's make one thing clear; the world you live in is hollow. It is plain and simple and contains only matter, which in itself does not possess anything of lasting value. The only way to create something of dignity, of true beauty in this world is by looking beyond its borders to search outside the mundane and enter into connection with that which lies beyond the safety of established form. To step into the realm of liberated wilderness of untamed fire and of that ancient chaos for which every true and potent artist has been a mouthpiece. There is a great abyss between this world and that place, an abyss which very few are able to cross. But by means for magick and communication with the Divine there are ways to penetrate into that vast darkness into that which lies beyond. To build bridges and open gateways to that terrible and wondrous place that lies outside the borders of the world. This is why we have chosen to look upon the spiritual characteristics of our world and this is why it is Divine. It acts as a mediator between high and low and a link between two worlds, and we have chosen to call it Watain (Opus Diaboli, 2012).

\section{Heavy Metal as Apophatic Liturgy}

When one considers the background to a performance such as this and accepts the context in which it arises, it seems that it provides a rejection of Pickstock's pseudo liturgy and her claim of the use of 'spectacle to induce order'. Only a superficial treatment of heavy metal culture would stop at the door and dismiss it all as mere spectacle. This superficial treatment of heavy metal culture is also dismissed by Deena Weinstein who in her important study of the sociology of heavy metal commented that: 
Perhaps the audience is a sheer creation of the genre and its commercial mediators. Although that is what some disparaging critics think that the audience is a sheer creation of the genre and its commercial mediators, it is not true. Music is the master emblem of Heavy Metal subculture, but not its meaning. Indeed, from the aspect of the audience, the music is a function of the lifestyles and mythologies of a youth group, and must be consistent with lifestyles and mythologies in order to be appropriated by the group. (Weinstein, 2000, p.99).

Of course now no longer exclusively a youth group, the lifestyles and mythologies of heavy metal extend into many fields, including political expression and even metal studies as an academic discipline. Admittedly some heavy metal is nothing more than spectacle, but this infection is not limited to this particular culture, the market and the alienating impact of technology, the separation of art from craft can be found in many places. As Erik Danielsson rather comically recently described his criticism of the Sunday mass in Metal Hammer Magazine: "I think it was when it got to the point of drinking coffee afterwards. That thought sickens me to this day, people in church drinking coffee" (Alderslade, 2013).

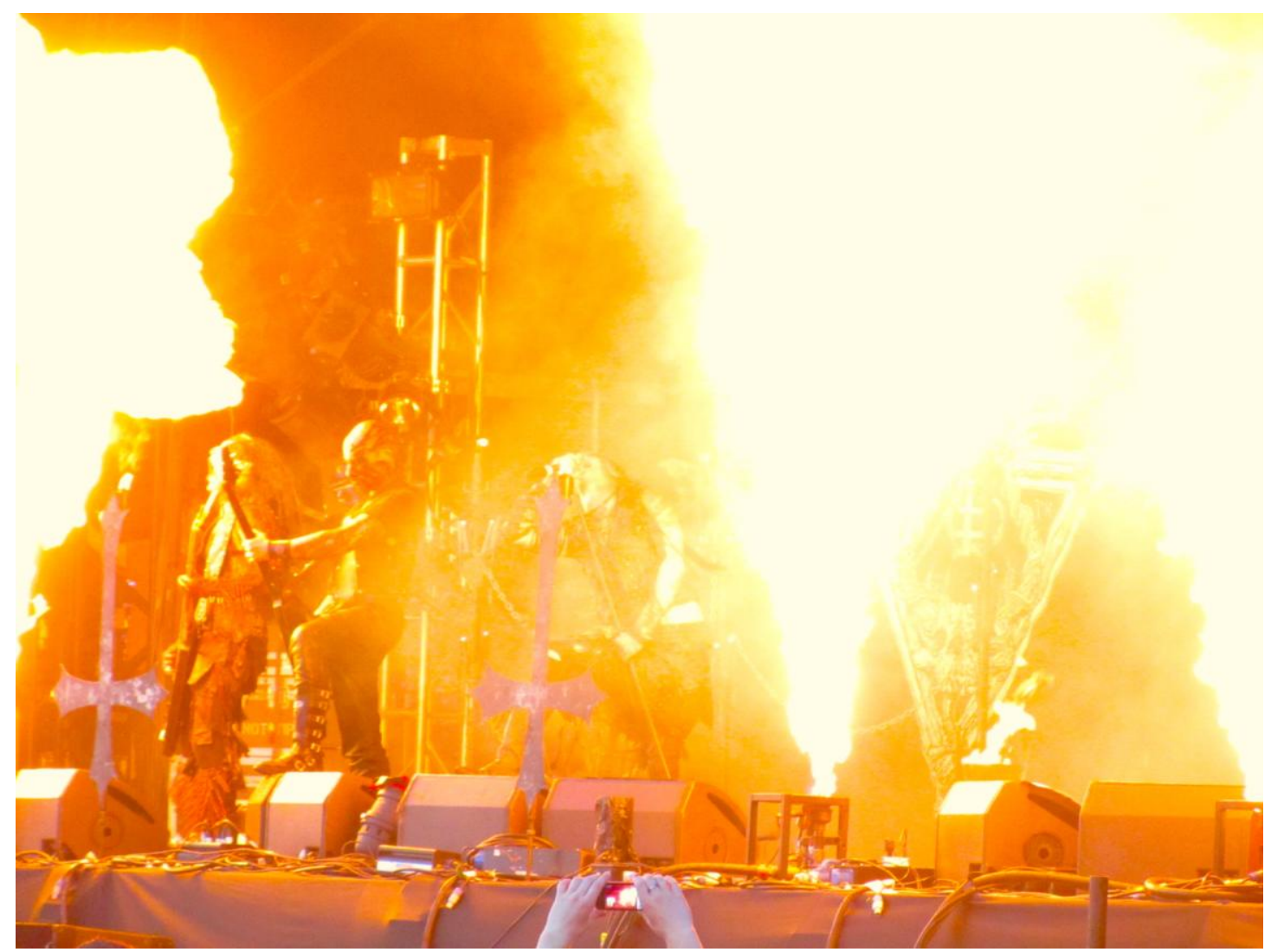

Image 4 Capturing a moment: More than just a spectacle? Watain, Bloodstock festival Catton hall, Derbyshire, image (C) Niall Scott

Authenticity is a frequently discussed term in the heavy metal world, in the sense that there is something sought after in being true. Expressed in Black Metal directly, for example in the phrase "True Norwegian black metal" 
from the same titled live album by Gorgoroth (2008) and in heavy metal more generally, this drive to authenticity presents a perspective (using Pickstock's insight) that rejects the postmodern subject in favour of achieving a true identity. This rejection is also carried out by the "liturgical subject" (Pickstock, 2000 161). It may be an ideal for the heavy metal subject, but is hard to sustain given that the heavy metal scene is replete with irony, and even the phrase 'True Norwegian Black Metal' has become a brand name associated with the music as a cultural export. This self-undermining complements Pickstock's criticism of liturgy becoming focused on the theatrical in its regularization. Indeed Lucas et al (2011) comment that black metal's very emergence can be related to a disenchantment of extreme metal's conformity to the music industry. The capacity for capitalism to distract and for technology to alienate remains an ever present threat to how aspects of modern culture and subcultures develop, but I think that in heavy metal we are either confronted by one of numerous paradoxes, or we encounter an oscillation between a range of ideals whose destruction is revealed at the moment of their conception and realization. However, although it appears to be merely a space of play, it seems that in the examples given from Behemoth and Watain, and other areas of heavy metal that are too numerous to mention, there is a goal being articulated of providing for reflective insight into the opportunity for transcendence. It is just that the matter concerns not presumption of a Christian pre-given lifeworld rather a transgressive goal that is nihilistic to its core.

Where heavy metal culture and black metal do succumb to pseudo liturgy, it can stand as useful critique on the heavy metal community as a project: for all intents and purposes the heavy metal event does itself a disservice in its repetition. By this I mean that the music event which in its expression is auditorily obscure and thus has meaning in its unmeaning, when repeated (and marketed), arguably fails to reach its true potential. This is a problem in general for the obsessive recording, capturing and repeating of events in popular and mass culture, infecting it with sameness, as Adorno and Horkheimer (2002) observed. As Joseph Russo (2010) comments in Hideous Gnosis the expression of the ideal frequently witnesses a decay where human interests sully the singularity of expression. Avoiding ritual as mere repetition it becomes clear that the distinction between ritual and liturgy is important to maintain in black metal, in the sense that Pickstock provides- there is an oscillation between the two In the same way that the true black mass ought to be a liturgy of total silence (in opposition to the word), the black metal liturgy has its potential in total noise. The recorded event, the repetition of sounds and words, the endless performance of a band's 'greatest hits' that are the hallmarks of the event as product lead to nothing in a different sense, not in the sense of an insight into the apophatic value of liturgy in a transcendent sense, but rather the valueless nothing of modern capitalist culture. Black metal specifically has the chance to advance itself in presenting apophatic liturgy, where one can use words and structures to annul meaning and structure. The meaning of the language, symbols and musical expression become equal to and identical with the event and cannot stand outside it (Nelstrop et al, 2009, p.55). Black metal holds in its power the possibility to perversely embrace an aspect of the very thing that Pickstock maintains 
concerning pseudo liturgy. She claims in language quite resonant of black metal theory, that pseudo liturgy fails to "restore the teleological to work, nor worship to enjoyment but reinforcing' as she puts it 'the cycling of both around a black abyss of recycled immanent spatiality" (Pickstock, 2000, p.170). Although this may be accurate regarding her claims regarding spectacle, I do not think it holds true for many aspects of heavy metal culture, especially black metal, where metal plays into the abyss rather than the distractions of spectacle that surround its edges. This approach to the apophatic is different though from the idea of an apophatic liturgy in terms of silence. Keiran Flanagan (1985) has defined apophatic liturgy as that which concerns the negative means through which one can come to know God, where this is encountered in silence. However this is understood in the context of the Christian liturgical rite of worship. Here silence is used to try and give meaning an understanding to the word of God; in a sense silence is being used to refer to meaning and expression. Silence as he puts it "provides a basis to the liturgical movement" (Flanagan, 1985, p.217). For black metal, this is inverted. I am using the apophatic in the sense that black metal directs one to an understanding of the transcendent value of absence, nothingness and ultimate meaninglessness grounding one's experience; where the enveloping noise of heavy metal refers to silence, rather than silence and absence having utility to refer back to liturgy. Where one may be confronted with inadequacy of language because of the obsession of trying to refer to things, in black metal, there is then no inadequacy in this use of noise and articulation as, there is no claim be made of trying to refer to something (i.e. God).

The key to this is opening the possibility for the event to never be repeated, recorded and so on, only remembered. Affirmation is then denied; the rock 'n' roll smug phrase- "you weren't there so you don't know what it was like" comes into its own. This builds then not only on the death of God, but the damning opportunity for the death of the word, a negation of expression entirely and what expression refers to: "words of my gospel scattered...this is the line between pure being and pure nothing" (Darski, 2009).

Perverting Augustine's phrase, we are engaged in the possibility of flashes of spiritual dark, inculcating an abysstopia. An apophatic liturgy in black metal does precisely the opposite of Franz Rosenzweig's claim concerning liturgical music. Rosenzweig (cited in Pickstock, 2000 p.162) makes the claim that music can be dangerous in its disruption of one's relationship to ordering of the day as it interrupts the relationship between time and one's normal activities. He holds that liturgical music restores order to one's relationship to time and events, preventing the dangerous features of music. In black metal as apophatic liturgy I claim this 'danger' is expanded, increasing the disruption of one's relationship between time and order to a threatening void; a freedom of open possibilities. In this sense, these black metal events could serve the void by dwelling in the immediate, or else the sense of negation required can only be achieved through the chaos of a second Babel, one that brings on desensitizing, blinding, deafening and temporal removal of the agent which is hinted at in an attempt at total noise. This is manifest in reminiscent of the attempts made by the drone metal art work of SunnO))), whose distorted sound and volume envelop those present 
to such a degree that some leave the performance space physically not able to deal with the noise.

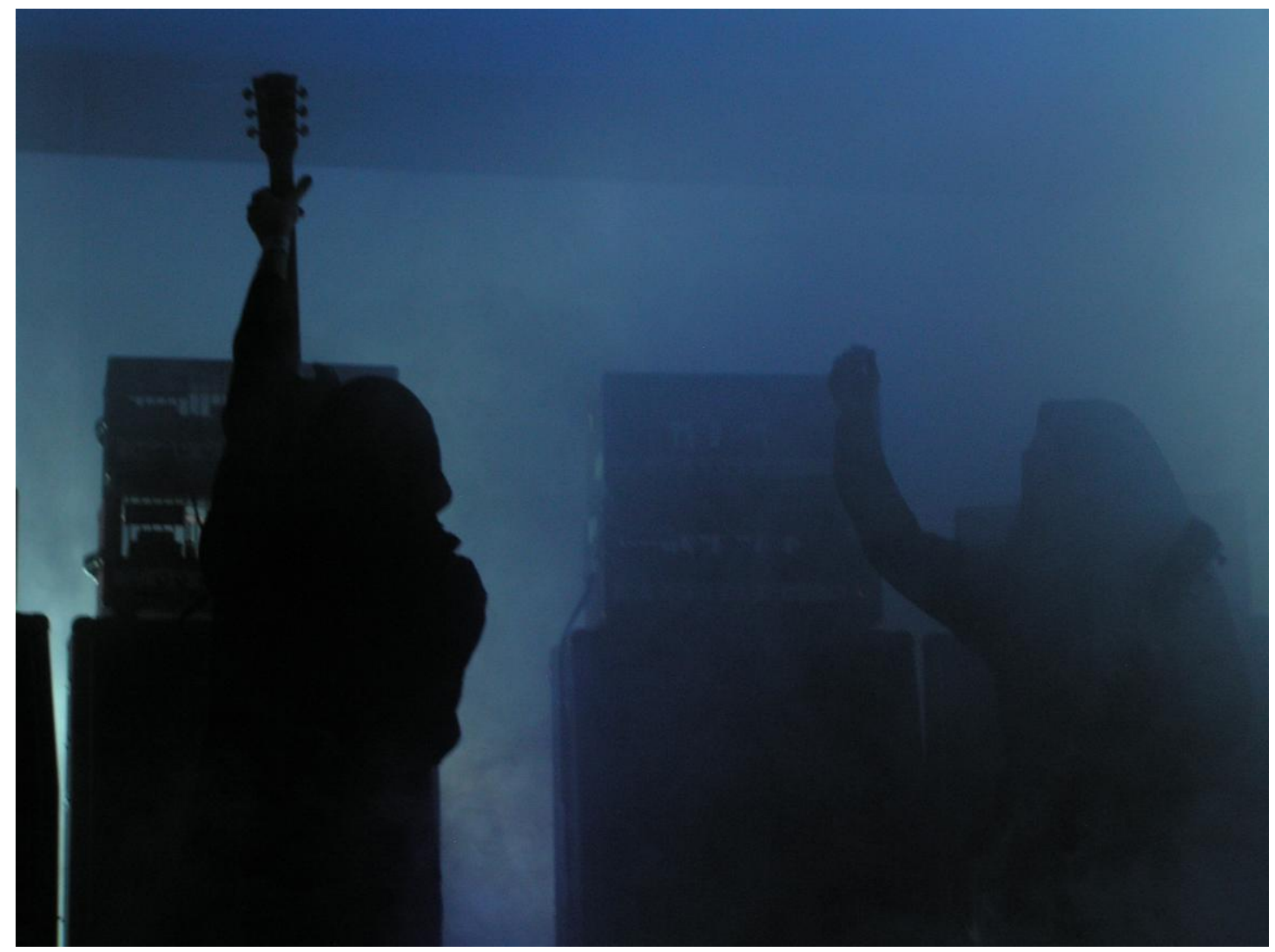

Image 5 SunnO))) Supersonic Festival, Birmingham 2009, image: (C) Niall Scott

Pickstock claims that Rosenzweig's treatment of music as dangerous sets up a dualism between the "mundane instrumental time and ecstatic, hysterical or oblivious time, whereas in a liturgical context, every ordinary moment points beyond itself to the eternal" (Pickstock, 2000, p.162), holding that no moment is without significance. This is a prelude to a complaint about the separation between work and pleasure, and she invokes the perspective from Adorno and Horckheimer that presents liturgy as "a place of resistance to capitalist and bureaucratic norms". Black metal can agree with this alienating effect entirely offered in Adorno and Horckheimer's work, but instead of pointing to an assumed Christian use of eternity, it offers a gateway to nothingness, and obliteration of the self in its celebration of meaninglessness. The self is distanced from oneself by way of being forced to by the impact of the enveloping noise that takes one beyond language and meaning.

\section{Conclusion}

In this paper I have presented a case to claim that heavy metal, specifically the subgenre of black metal opens the opportunity for being considered in terms of liturgy. I identified some easily recognizable features of heavy metal culture at the outset that at a glance correspond to the temporal features of liturgy, for example the regular festival events that mark out particular moments in time in the heavy metal calendar. Following on from a definition of liturgy, I focused on Catherine Pickstock's political and 
philosophical understanding of liturgy. Although this was a useful framework from which heavy metal and liturgy can be discussed, I am critical of the possible dismissal of heavy metal and in particular black metal as being described as pseudo liturgy, the music performances prone to be treated merely as an example in the arts as spectacular consumer events. Instead I offered the case that black metal and by extension other areas of heavy metal, although not immune to this criticism, where it is commodified and bound up in the market, can be treated as an apophatic liturgy; a liturgy of negation. As an apophatic liturgy, heavy metal provides for the transcendent consideration of meaninglessness, absence and nothingness as a grounding for the relationship between the real and ideal, rather than liturgy necessarily carrying an assumption of a pre-given Christian lifeworld.

\section{Bibliography}

Abgott (2009) Godfather in Black, CD, Helvete and Hate Recordings.

Adorno T. and Horckheimer, M. (2002) Dialectic of Enlightenment, Stanford, CA, Stanford University Press.

Alderslade, M. (2012) 'It's Official Heavy Metal is a Bigger Religion than Scientology, Druidism and Um... Shamanism', Online - Metal Hammer http://www.metalhammer.co.uk/news/its-official-heavy-metal-is-abigger-religion-in-the-uk-than-scientology-druidism-and-umshamanism/ (Accessed 20 March 2014)

Alderslade, M. (2013) 'Roots Bloody Roots'

http://www.metalhammer.co.uk/news/watains-erik-danielsson-people-in-achurch-drinking-coffee-it-sickens-me/ (Accessed 20 March 2014)

Allett, N. (2011) The Extreme Metal 'Connoisseur', Popular Music History, vol. 6.1/6.2, pp.164-179.

BBC Arena (2014) 'Heavy Metal Fan Letters' http://www.bbc.co.uk/programmes/b006pn88/profiles/heavymetal (Accessed 04 ${ }^{\text {th }}$ June 2014)

Behemoth (2009) Evangellion, Metal Blade Records.

Behemoth (2014) The Satanist, Nuclear Blast recordings.

Brassington, I. (2010) 'Niall Scott reveals his Dark Side', Journal of Medical Ethics Blog, http://blogs.bmj.com/medical-ethics/2010/02/09/niall-scottreveals-his-dark-side-as-if-it-was-ever-hidden/ (Accessed $4^{\text {th }}$ June 2014). 
Brown, A. (2011) 'Metal Studies? Cultural Research in the Heavy Metal Scene', Journal for Cultural Research, vol. 15, no. 3, pp.209-212.

Danielsson, E, Watain (2000) On Horns Impaled, Rabid Death's Curse, Apocalyptor Records.

Danielsson, E. (2008) Kunberg, M. (director) Black Metal Satanica DVD, Cleopatra release.

Danielsson, E. (2012) Opus Diaboli, Watain, His Masters Voice.

Darski, N. (2012) Evangellion, Behemoth, Nuclear Blast recordings.

Darski, N. (2014) The Satanist, Behemoth, Nuclear Blast recordings.

Dunn, S. (2005) Metal: A Headbanger's Journey, DVD, Seville Pictures.

Edgar, A. (2012) 'Sport as Liturgy: Towards a Radical Orthodoxy of Sport', Studies in Christian Ethics vol. 25, no.1, pp.20-34.

Flanagan, K. (1985) 'Liturgy, Ambiguity and Silence: The Ritual Management of Real Absence', The British Journal of Sociology, vol. 36, no. 2, pp.193-223.

Flynn, R. (2011) Unto the Locust, Machine Head, Roadrunner records.

Fortescue, A. (2009 [1910]) 'Liturgy,' in The Catholic Encyclopedia, New York, Robert Appleton Company, http://www.newadvent.org/cathen/09306a.htm (Accessed 20 March 2014).

Gorgoroth (2008) True Norwegian Black Meal-Live in Grieghallen, Regain recordings.

Guibert, J and Sklower, J. (2013) 'Hellfest: The Thing That Should Not Be?' in Hjelm, T., Kahn-Harriis, K. and Levine, M. (eds) Heavy Metal Controversies and Countercultures, Bristol, Equinox press, pp.98-113.

Hagen, R. (2011) 'Musical Style, Ideology and Mythology in Norwegian Black Metal,' in Wallach, J; Berger H.M; and Green P.D., Heavy Metal Rules the Globe: Heavy Metal Music Around the World, Durham and London, Duke University Press.

Hecker, P. (2012a) Turkish Metal Music: Meaning and Morality in a Muslim Society, Farnham, Ashgate.

Hecker, P. (2012b) 'Heavy Metal in a Muslim Context: The Rise of the Turkish Metal Underground', in Scott, N. (ed.) Reflections in the Metal Void, Oxford, Inter-disciplinary Press, pp. 212-139. 
Hopper, J (2009) Back to the Land with the Wolves, Chicago Tribune, May 15 http://articles.chicagotribune.com/2009-0515/entertainment/0905130408 1 band-members-satanic-metal (Accessed 4th June 2014).

Levine, M. (2008) Heavy Metal Islam, New York, NY, Three Rivers Press.

Lloyd, V. (2011) 'Liturgy in the Broadest Sense,' New Blackfriars, vol. 92, no. 1037, pp.71-89.

Lucas, C, Deeks, M. and Spracklen, K (2011) 'Grim up North: Northern England, Northern Europe and Black Metal' Journal for Cultural Research, vol. 15, no. 3, pp.279-297.

Marcuse, H. (1991) One Dimensional Man, London, Routledge.

Masciandaro, N., (2010) Hideous Gnosis, Black Metal Theory Symposium I, New York, Create space independent publishing platform.

Masciandaro, N. (2009) Black Sabbath's Black Sabbath, a Gloss on Heavy Metal's Originary Song, Online - Reconstruction, 9.2, http://reconstruction.eserver.org/092/masciandaro.shtml (Accessed 20 ${ }^{\text {th }}$ March 2014).

Miller, J.H. (1957) 'The Nature and Definition of the Liturgy', Theological Studies vol. 18, pp.325-356.

Moberg, M. (2012) 'Turn or Burn: Approaching the Peculiar Case of Christian Heavy Metal', in Scott, N. (ed) Reflections in the Metal Void, Oxford, Inter-disciplinary Press, pp.49-67.

Moberg, M. (2013) 'The Double Controversy of Christian Metal Music,' Popular Music History, vol. 6.1/6.2, pp.85-99.

Nelstrop, L. Magill, K. and Onishi, B.B. (2009) Christian Mysticism: An Introduction to Contemporary Theoretical Approaches, Farnham, Ashgate.

O'Boyle, T. (2012) Bloodstock Festival Review, The Quietus, $17^{\text {th }}$ August [online] Available from http://thequietus.com/articles/09748-bloodstock-festival-review (Accessed 20th March 2014).

Patterson, D. (2013) Black Metal: Evolution of a Cult, Washington, Feral House.

Pickstock, C. (2000) 'Liturgy, Art and Politics', Modern Theology, vol.16, no. 2, pp.159-180. 
Purcell, N. (2003) Death Metal Music, the Passion and Politics of a Subculture, London, McFarland \& Co.

Russo, J. (2010) 'Perpetue Putesco- Perpetually I Putrefy', in Masciandaro, N. (ed.) Hideous Gnosis, Black Metal Theory Symposium I, New York, Create space independent publishing platform.

Scott, N. (2010) 'Black Confessions and Absu-lution', in Masciandaro, N. (ed) Hideous Gnosis, Black Metal Theory Symposium I, New York, Create space independent publishing platform.

Scott, N. (2011) 'The Deafening Threat of the A-political,' Popular Music History, vol. 6.1/6.2, pp.224-239.

Scott N., (2012) Reflections in the Metal Void, Oxford, Inter-disciplinary Press.

Smith, B. (2006) Interview with Wolves in the Throne Room, http://www.nocturnacult.com/WITTRint.htm [online] (Accessed $20^{\text {th }}$ March 2014).

Till, R. (2010) Pop Cult: Religion and Popular Music, London, Continuum.

Weinstein, D. (2000) Heavy Metal, The Music and its Culture, Cambridge, MA, DaCapo Press. 